\title{
Kunstpsykoterapi og spiseforstyrrelser
}

\author{
Kunst kan hjelpe oss til å se bak det umiddelbare og inn i det ukjente. Kunstterapiens styrke ligger \\ i bildets visuelle språk. Livshistoriene våre er sanset med bilder, lyder, lukter og berøring før de kan \\ bli verbale fortellinger.
}

\section{Åse Minde}

asemin@ous-hf.no

Oda Vigdal

Tori Flaatten Halvorsen

Kunstterapien fremmer kontakten med sansehistoriene. De indre bildene som fremkalles i den kreative prosessen, uttrykkes gjennom kunstverket. Dette skapte uttrykket stimulerer til nye sanseerfaringer - og nye bilder oppstår.

Spiseforstyrrelsen har gjort at pasienten har fjernet seg fra sine egne følelser. Han eller hun er blitt observatør til eget liv. I et selvbilde fastlåst $\mathrm{i}$ tvangstanker rundt mat og kropp kan kunsten hjelpe pasienten til å finne tilbake til sitt indre opprinnelige språk - og til å kunne romme seg selv.

I den kreative kunstterapeutiske prosessen kan vi eksperimentere med ulike materialer, form og farge. Vi kan bygge opp og bryte ned i en kontinuerlig søken etter å finne frem til kunstverkets kjerne eller det «sanne jeg». Dette er spesielt viktig $i$ arbeidet med pasienter med spiseforstyrrelser.

Innen en psykodynamisk forståelsesramme ser vi spiseforstyrrelsen som en selvforstyrrelse. I mangel på å kjenne seg selv innenfra blir pasienten ytrestyrt. Den avmagrede, tynne kroppen er blitt identiteten. Enhver endring blir truende, fordi vektøkning blir sidestilt med tap av iden- titet. Pasientens liv kan være preget av et konstant tankekjør rundt mat og kropp. Det kan oppleves som å være fengslet i egen kropp.

Kunsten kan være en viktig vei ut av spiseforstyrrelsen. Tusjtegningene til Oda Vigdal viser skjøre og avmagrede kropper tusjpennen gir full kontroll. Gjennom kunsten mestrer hun etter hvert det å bevege seg fra den konkrete kroppen og tvangstankene. Hun begynner å eksperimentere med andre materialer, for eksempel silkepapir. Hvert lag silkepapir blir som et lag hud som kan beskytte den avmagrede kroppen. Slik får hun langsomt kontakt med sin sanselighet. Gradvis kan hun tåle vektøkning og godta sin egen kropp og ta bolig i denne.
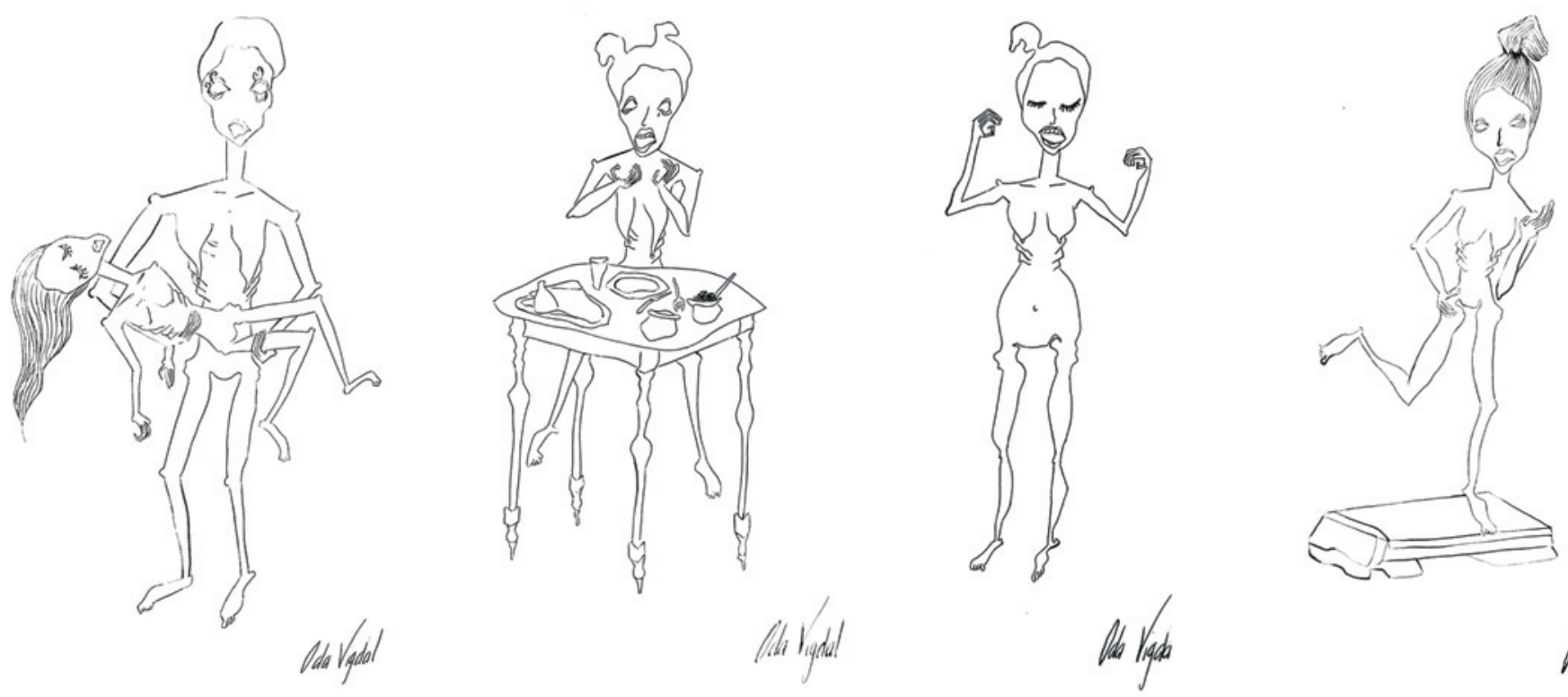

«Fortvilelse - sykdom - overlevelse» - Oda Vigdals bilder 
Anes bilder formidler både tristhet, tvang, sinne og humor. I den kreative prosessen fikk hun kontakt med sin humoristiske sans. Gjennom bildene evnet kunstneren å se på paradoksale $\mathrm{i}$ tvangen. Hun mestret så å kunne le av den. Fra å være fastlåst i tvangstanker og ritualer rundt mat og kropp har kunstterapien hjulpet henne til å bevege seg ut fra det fastlåste selvbildet til å bli et «selv».

Ane skriver: «Når man ikke har de rette ordene og ikke greier å forklare eller selv vite hva man tenker eller føler, da kan det være nyttig med en ny uttrykksform. I starten var det vanskelig. Hva i alle dager er det meningen jeg skal bruke det blanke arket

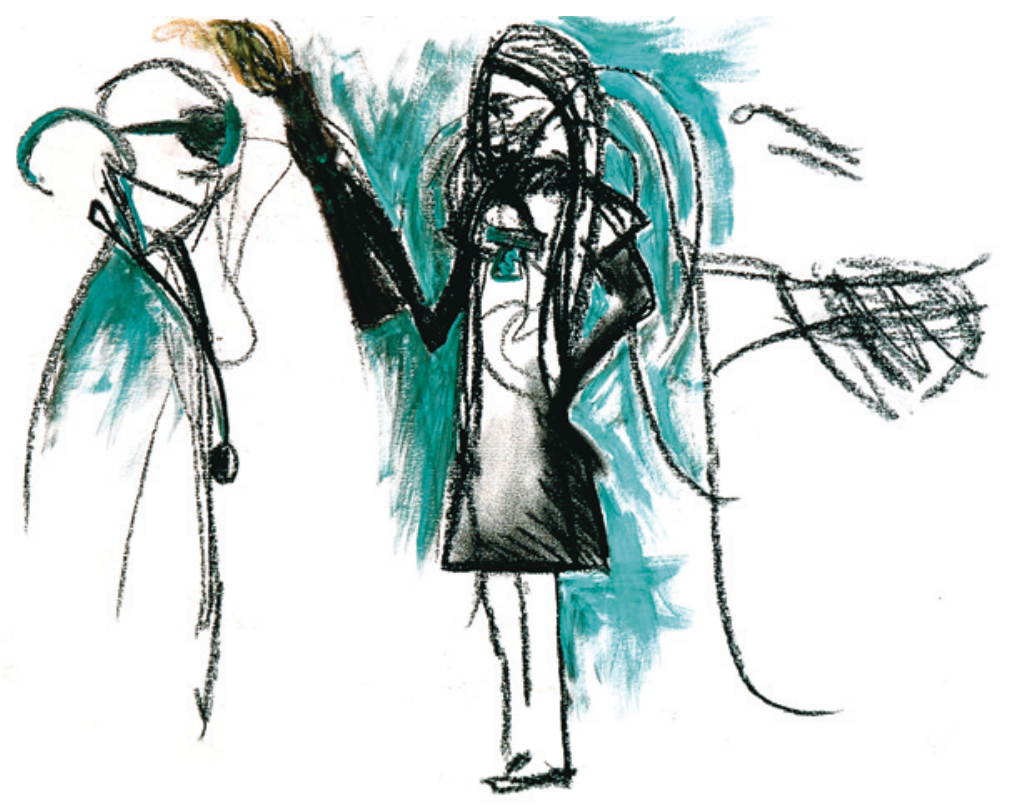

$\operatorname{Anc} 25.10 \cdot 1^{2}$

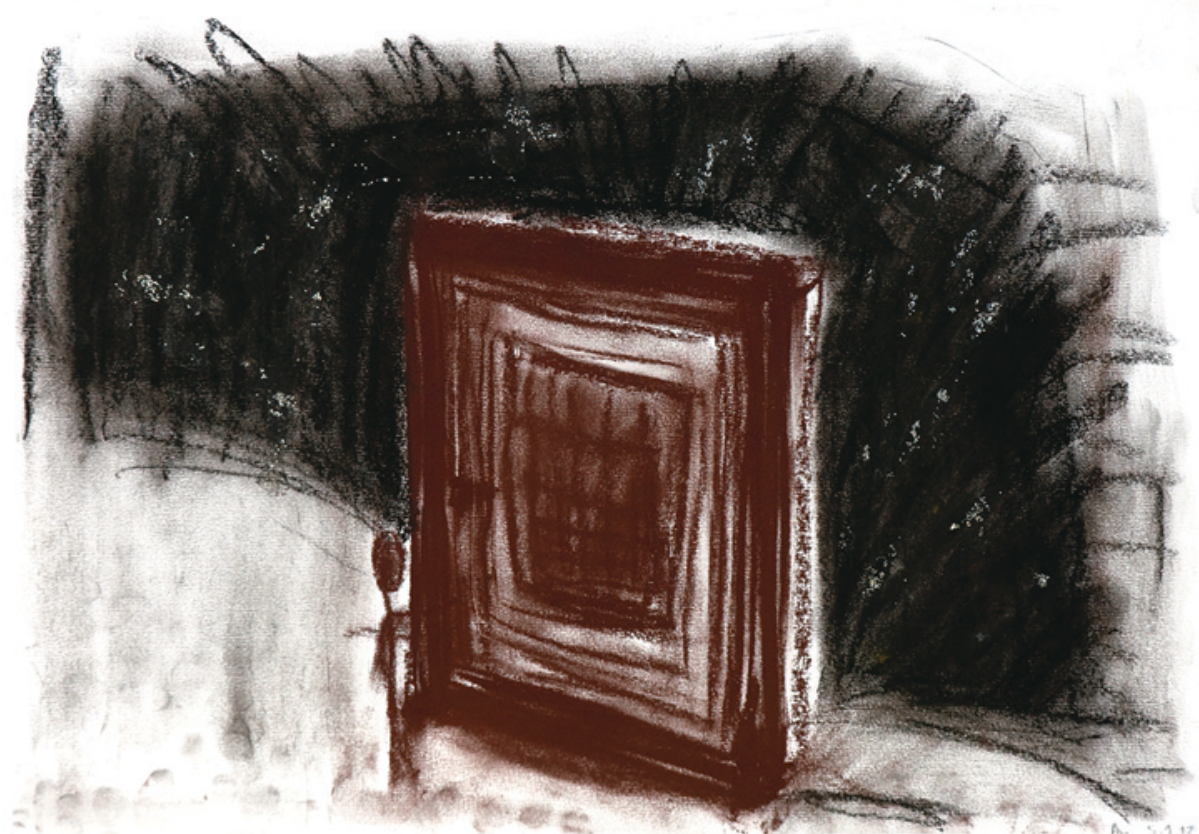

Anes bilder til? Prestasjonsangsten melder seg - jeg kan jo verken tegne eller male. Så prøver man å krote litt, da. Og når man får gjøre det ofte, så blir det ikke så nøye, på en måte. Man får alltids en ny sjanse, så det må ikke nødvendigvis bli så fint.

Jeg skulle ønske jeg kunne la hånda fly over arket uten at hjernen setter grenser, men det synes jeg fortsatt er vanskelig. Kritt, kullstifter eller maling? Det er opp til meg. Noen ganger blir det bare en stor, grå krusedull, gjerne med hoggtenner og sinnaøyne. En trist fettklump med feite armer og ben og surmunn er en gjenganger. En sjelden gang kommer det et helt maleri.

Tanker, følelser, hendelser, drømmer og mareritt. Alt kan tegnes. Av og til ligger det en plan bak. En drøm som må finnes ut av. Det kan dukke opp ting der jeg ikke visste om, men som blir synlige i streken. Noen tegninger blir stygge, skumle eller ekle, og kanskje dukker det opp ting det er nyttig å ta videre i samtale. Andre blir rare og komiske, og vi må le sammen av det vi ser. Og det er da mye terapi i en god latter?»

\section{Åse Minde (f. 1950)}

har en mastergrad i kunstpsykoterapi. Hun var initiativtaker til opprettelsen av Spiseforstyrrelsespoliklinikken på Gaustad, Seksjon for personlighetspsykiatri, Oslo universitetssykehus, der hun er enhetsleder. Hun er forfatter av flere fagbøker innenfor kunstpsykoterapi. Forfatter har fylt ut ICMJE-skjemaet og oppgir ingen interessekonflikter.

\section{Oda Vigdal (f. 1992)}

er sykepleierstudent.

Forfatter har fylt ut ICMJE-skjemaet og oppgir ingen interessekonflikter.

\section{Tori Flaatten Halvorsen (f. 1965)}

er spesialist i allmennmedisin, fastlege ved Studentsamskipnaden i Oslo - SiO Helse og overlege ved Spiseforstyrrelsespoliklinikken på Gaustad, Seksjon for personlighetspsykiatri, Oslo universitetssykehus. Hun sitter i Helsedirektoratets arbeidsgruppe for Nasjonale faglige retningslinjer for utredning og behandling av spiseforstyrrelser.

Forfatter har fylt ut ICMJE-skjemaet og oppgir ingen interessekonflikter.

Mottatt 8.10. 2014, første revisjon innsendt 11.10. 2014, godkjent 15.10. 2014. Redaktør: Are Brean.

Podkast på www.tidsskriftet.no 